\title{
Theoretical Prediction of Thermo- Physical Properties of Beef Tallow Based Biodiesel
}

\section{Gokul Raghavendra Srinivasan}

Research Schola Vellore

$\mathrm{CO}_{2}$ Research and Green Technologies

Centre

Research Co-ordinato Bharath Institute of Higher Education and Research Chennai,

India

\section{Ranjitha Jambulingam}

Associate Professor Vellore Institute of Technology $\mathrm{CO}_{2}$ Research and Green Technologies Centre Vellore, India

This present study deals with the theoretical prediction of thermo-physical properties of waste beef tallow biodiesel by means of developing mathematical correlations using fatty acid esters. Waste beef tallow was rendered from animal slaughter houses and tanneries' leather fleshing wastes; and was transesterified into biodiesel through base catalyzed ethanolysis. Ethyl palmitate (C16:0), ethyl oleate (C18:1) and ethyl stearate (C18:0) were identified as the dominant fatty acid ethyl esters (FAEs) in the tallow biodiesel, with their corresponding distribution as $37.36 \%, 25.17 \%$ and $14.78 \%$ respectively. Mathematical correlations were developed for predicting density, kinematic viscosity, cetane number and higher heating value using statistical regression by maintaining molecular weight (Mwt) and number of unsaturated bonds (NE) of FAEs as input variables. Overall, thermo-physical properties of the biodiesel were computed from the properties calculated using the correlations, mass fraction and mole fraction of characterized FAEs; and was compared with the experimental data determined according to ASTM D976 standards. Accordingly, the average absolute deviation (AAD) and average Absolute Percentage Error (AAPE) were calculated as 3.55, 0.815\% for density; 0.12, 4.79\% for kinematic viscosity; 2.14, 6.56\% for cetane number and $0.23,1.14 \%$ for higher heating value respectively. From these correlations, it showed that kinematic viscosity, cetane number and higher heating value increased with molecular weight of the FAEs but reduced with increase in unsaturation; in contrast, density of biodiesel increased with its unsaturation but decreased with increasing molecular weight. In conclusion, the predicted values of density, kinematic viscosity, cetane number and higher heating value were found to be in reasonable agreement with experimental values.

Keywords: Beef tallow biodiesel, Fatty acid ethyl esters, Statistical regression, Molecular weight, unsaturated double bonds.

\section{INTRODUCTION}

The demand for biodiesel is growing widely in both developed and developing countries to meet their increasing energy demand in a sustainable way. Biodiesel is the common name for any fatty acid alkyl ester produced by transesterifying fatty acids in triglyceride molecule present in animal fat or vegetable oil, with short chained alcohol in the presence of catalyst under optimized condition. Especially, it is widely known for its fair advantages like non-toxicity, high biodegradability, enhanced engine performance with reduced engine parts wear and emissions; thereby making it a self-sustaining and environmental friendly biofuel [1]. In fact, biodiesel is superior to diesel fuel in terms of its reduced $\mathrm{CO}$ and NOx emission, higher sustainability and lower impact on the environment.

In general, the quality of biodiesel is decided by its

Received: January 2019, Accepted: March 2020

Correspondence to: Dr Ranjitha Jambulingam

Vellore Institute of Technology, Vellore, India

$\mathrm{CO}_{2}$ Research and Green Technologies Centre

E-mail: ranjitha.j@vit.ac.in

doi: 10.5937/fme2003600R

(C) Faculty of Mechanical Engineering, Belgrade. All rights reserved thermo-physical properties which are in turn reflected in its performance, combustion and emission (PCE) characteristics during engine application [2]. Density $(\rho)$, kinematic viscosity $(v)$, cetane number $(\mathrm{CN})$ and higher heating value (HHV) are the important thermophysical properties which signify the quality of biodiesel and have very good influence during its combustion [3].

Supporting this, density of the biodiesel influences its fuel mass to be injected inside the cylinder and serves as a precursor for regulating the fuel injection system to induce complete combustion [4]. Also, it is regarded as a salient feature for designing biodiesel reactors, separation units, plumbing and storage tanks [5]. Furthermore, density of the biodiesel is entirely dependent on its characterized FAEs and their degree of unsaturation [6]. Likewise, viscosity of biodiesel defines about its spray characteristics and atomization upon injection inside the cylinder [7]. Thus, biodiesel with low viscosity denies sufficient lubrication necessary for precise fitting in fuel injection pumps which results in leakage or component wear [8]. Contrarily, biodiesel with high viscosity leads to poor atomization due to formation of large droplets upon injection followed by 
incomplete combustion resulting in increased deposition of carbon content (in case of highly unsaturated biodiesel), which induces polymerization reaction [9]. Like density, viscosity of biodiesel are also completely influenced by its FAEs in addition to their degree of unsaturation [10].

Besides, cetane number is a dimensionless fuel property of biodiesel which serves as an indicator in defining its ignition delay, which in turn explains about the premixed and diffusion combustion during power stroke [11]. And then, it also decides the heat release profile; combustion noise and emission characteristics of the biodiesel, thereby accrediting it as the most influential parameter to be determined for all diesel fuels [12,13]. Apparently, higher CNs were noted for long chain saturated biodiesel than compared to short or unsaturated biodiesel [14]; thus, implying the significance of chain length and unsaturation in deciding the cetane number of biodiesel. Further, higher heating value of biodiesel characterizes its probable energy content available in it [15] and always occurs lesser than diesel fuel due to the presence of oxygen and absence of sulphur content in it. In consequence of reduced HHV, more amount of biodiesel will be consumed to produce equivalent work output derived from diesel fuel, thereby resulting in reduced overall engine performance and increased fuel consumption [2]. Like other properties, HHV is also deeply influenced by the FAEs profile and their degree of unsaturation in the biodiesel; and tends to be lower for biodiesel with unsaturated FAEs.

Considering their significance in deciding the quality of biodiesel, these properties must be always evaluated with reference to permissible standards, to ensure its compatibility with CI engines. Inspite of their significance, these properties are evaluated occasionally due to various technical challenges like insufficient availability of test samples and time consumption apart from the necessity to strictly adhere to standard protocols, making it complex and exhaustive. However, this can be over ruled by developing mathematical correlations to predict these vital properties instead of exhaustive experimental process. Eventually, this approach is highly useful in predicting the theoretical values of these properties and can be developed by correlating various factors associated to the biodiesel. As a matter of fact, it was clearly evident that these properties are deeply influenced by the characteristics of individual FAEs and their extensive molecular properties [16]. Accordingly, numerous studies have been carried out with an aim of developing prediction models and mathematical correlations for evaluating the properties of biodiesel using the structural properties of their FAEs.

Beginning with, Knothe, 2005 proposed in his study that the properties of biodiesel were highly dependent on their fatty acid alkyl esters, which in turn depended on the structural features of fatty acid chain and their alcohol moiety. Furthermore, the study strongly concluded that biodiesel properties like viscosity, lubricity, $\mathrm{CN}$, oxidative stability, cold flow, HHV and exhaust emissions were entirely dependent on their fatty acids alkyl esters. In addition, properties like viscosity, melting point, cetane number and HHV increased with increasing carbon chain length while decreased with increase in degree of unsaturation [3].

Among the studies related to the theoretical prediction, Pratas et al., 2010 predicted the density and viscosity of fatty acid alkyl esters theoretically by developing predictive models with temperature as a variable and comparing them with experimental values. For the purpose of study, eight methyl esters and seven ethyl esters were measured for their density and viscosity at different atmospheric pressure and temperature (273.15 to $363.15 \mathrm{~K})$. Predications made for density using GCVOL method was found to be highly reliable with only $<1 \%$ deviation for fatty acid methyl esters (FAMEs) and 1.5\% deviation for fatty acid ethyl esters (FAEEs). Similarly, in case of predicting viscosity, the Ceriani and Meirelles (CM) method was found to be highly effective than Marreiro and Gani (MG) method in view of their minimal deviation in their experimental and predicted result by $4.53 \%$ for FAMEs and $7.92 \%$ for FAEEs [17]. Likewise, similar study predicted the density and viscosity of FAMEs by establishing simple correlations using their composition (in \%wt.). Eventually, these correlations predicted the density with an accuracy of $98.5 \%$ while viscosity for $97.1 \%$; and guaranteed for the prediction of these physical properties for any biodiesel by simply using their FAME compositions. In conclusion, the mean predicted value for density was found between $861.7-885.7 \mathrm{~kg} / \mathrm{m}^{3}$ and viscosity was found between $4.31-5.64 \mathrm{~mm}^{2} / \mathrm{s}$ [18].

Likewise, Freitas et al., 2010 attempted for evaluating the predictive models for determining the viscosity of biodiesel theoretically. Subsequently, predictive models based on Krisnangkura's, Ceriani's, Yuan's proposed and revised models were evaluated for their predictive capability. Ultimately, the results yielded an average deviation of $4.65 \%, 5.34 \%, 7.25 \%$ and $8.07 \%$ for revised Yuan's model followed by Yuan's model, Krisnangkura's model and Ceriani's model respectively and were verified in accordance with viscosity for biodiesel blended diesel fuels. Therefore, this study strongly recommended revised Yuan's model as an effective predictive model for determining the viscosity of biodiesel theoretically [7]. Another way, Roosta and Bardool, 2019 developed three predictive models for determining the viscosity of biodiesel by correlating 226 data points (viscosity at various temperatures ranging between 263.15 and $373.15 \mathrm{~K}$ ) corresponding to 16 different fatty acid methyl esters (FAMEs). Starting with, the first model employed temperature as a variable and it demonstrated minimal average absolute relative deviation (AARD) of $0.97 \%$. And then, second model was developed by considering number of carbon atoms and number of double bonds in ester molecules as two independent variables; and exhibited a minimal AARD of $2.28 \%$. Finally, the third model was established using the molar average of viscosity of FAMEs along with their availabilities; by correlating 185 data points (viscosity at various temperatures ranging between 263.15 and $373.15 \mathrm{~K}$ ) corresponding to 23 different FAMEs. Eventually, the minimal AARD was recorded as $2.96 \%$; and was found to be highly reliable for predicting the viscosity of biodiesel theoretically [19]. 
Besides, Giakoumis and Sarakatsanis, 2019 reviewed 16 predictive models developed for theoretically predicting the $\mathrm{CN}$ using the structural features of fatty acid alkyl esters like carbon chain length, molecular weight, number of double bonds and degree of unsaturation. This study used experimental data related to cetane number and fatty acid composition referenced from nearly 50 literatures and coefficient of determination as effective tool in deciding the most effective predictive model. In specific, this study strongly recommended the predictive model developed by Giakoumis and Sarakatsanis in view of their high accuracy and predictive capability. However, this study also concluded that increasing number of variables like chain length, molecular weight and degree of unsaturation in predictive models resulted in lower accuracy results [12].

In addition to this, Hong et al., 2015 developed two empirical correlations for determining HHV of fatty acid methyl esters (FAMEs) and fatty acid ethyl esters (FAEEs) by employing molecular weight and number of unsaturated double bonds as independent variables. In fact, this study proposed that HHV was directly proportional to molecular weight and inversely proportional to degree of unsaturation in the ester molecules. Moreover, the constants in the developed equations were found to be higher for molecular weight, in case of FAEEs and higher for double bonds, in case of FAMEs. Thus, it can be strongly concluded that the HHV of biodiesel was strongly influenced by the molecular weight of FAEs and above all, the effect of molecular weight and number of unsaturated double bonds was found to be more on FAEEs than FAMEs [20].

In the present paper, simple yet reliable linear equations were developed for predicting the thermo-physical properties (density, kinematic viscosity, cetane number and higher heating value) of biodiesel from waste beef tallow by considering the molecular weight and number of double bonds in their characterized FAEs as two independent variables. Eventually, molecular weight serves as an indicator for length and number of carbon atoms in the ester molecules while numbers of double bond signifies its degree of unsaturation. The developed correlations were evaluated for their absolute deviation and $\%$ error by comparing the theoretical values with experimental thermo-physical data for waste beef tallow biodiesel along with other ethanol based biodiesel referenced from existing literatures.

\section{MATERIALS AND METHODOLOGY}

\subsection{Sample Collection}

Waste beef tallow was rendered from fleshing and subcutaneous wastes collected from leather tanneries and animal slaughter houses respectively. Beginning with, the collected wastes were autoclaved @ 120 C, 2 bar pressure to separate tallow from non-fatty organic wastes [21]. The rendered tallow was washed with water at $60^{\circ} \mathrm{C}$ to remove any solid sediment and dehydrated at $110^{\circ} \mathrm{C}$ to remove any moisture content from it. Following this, the tallow was degummed by treating it with orthophosphoric acid under continuous heating with intermittent stirring as carried out by
Srinivasan et al., 2018 [22], to remove phospholipids from it. Later on, the refined tallow was preserved using refrigeration to avoid any contamination and prevent rancdification (oxidation of tallow).

\subsection{Preparation of beef tallow biodiesel}

The refined tallow was subjected for base catalyzed transesterification using ethanol as solvent. Hence, the tallow was transesterified into ethyl tallow biodiesel by maintaining the reaction parameters as follows: oil to ethanol molar ratio - 1:6; catalyst concentration - potassium hydroxide $(\mathrm{KOH})$ of $0.5 \%$ wt. of tallow taken; reaction temperature $-60^{\circ} \mathrm{C}$, reaction duration -120 minutes [2]. Post completion of reaction, the mixture was separated in separating funnel under the influence of gravity which separated biodiesel layer at top and glycerol at bottom. The separated biodiesel was water washed repeatedly and dehydrated to remove any impurities and moisture content, respectively, in it.

\subsection{Quantification of Fatty Acid Esters (FAEs)}

Starting with, the fatty acid ethyl esters (FAEs) in the tallow biodiesel were quantified using Gas Chromatography and Mass Spectrometry (GC-MS). Accordingly, FAEs were identified by the peak obtained at their corresponding retention time and were quantified based on the area occupied by those peaks. Following this, the quantified FAEs were considered for the purpose of developing empirical correlations for the thermo-physical properties. Technical specifications of GC-MS equipment have been presented in table 1 [2].

Table 1: Technical specifications of Gas chromatograph Mass spectrometer [2]

\begin{tabular}{|c|c|}
\hline \multicolumn{2}{|c|}{ Gas Chromatograph } \\
\hline Equipment & Agilent 6890 chromatograph \\
\hline Injector Liner & direct/2 mm \\
\hline Column & $(25 \mu \mathrm{m}$ ID, $0.25 \mu \mathrm{m}$ thickness) \\
\hline Split Ratio & $10: 01$ \\
\hline Oven Temperature & $35^{\circ} \mathrm{C} / 2 \mathrm{~min}$ \\
\hline Ramp & $20^{\circ} \mathrm{C} / \mathrm{min} @ 300^{\circ} \mathrm{C}$ for 5 min \\
\hline Helium Carrier Gas & (constant flow mode) \\
\hline \multicolumn{2}{|c|}{ Mass Spectrometer } \\
\hline Equipment & JOEL GC mate II bench top \\
\hline Type & Double focusing magnetic sector \\
MS
\end{tabular}

\subsection{Experimental evaluation of thermo-physical properties}

Necessary physico-chemical properties like density, kinematic viscosity, cetane number and higher heating value were determined as per ASTM standards to assess the quality of tallow biodiesel. Hence, the density of biodiesel was determined based on ASTM D1298 
method using hydrometer whereas the kinematic viscosity of biodiesel was determined using calibrated glassviscosity tube mentioned as per ASTM D445 method. Similarly, cetane number of biodiesel was determined as per ASTM D613 method whereas higher (gross) heating value was determined using bomb calorimeter by as per ASTM D240 method. Simultaneously, these experimental values were used to compare with theoretical values calculated using the correlations and analyse the average $\%$ error and deviation between them.

Likewise, thermo-physical properties for characterized FAEs used in calculations were referenced from standard literatures corresponding to biodiesel quality, standards and properties determined as per ASTM standards $[3,23]$. Accordingly, four sets of data series were developed for each thermo-physical property and comprised of consolidated values of corresponding property for different FAEs. Later on, these data series were used in developing the correlations for predicting the thermophysical properties.

\subsection{Mathematical Modelling of Empirical Correlations}

The thermo-physical properties of beef tallow biodiesel were evaluated theoretically, by developing empirical correlations using the data series using DESIGNEXPERT software. Accordingly, the molecular weight $\left(\mathrm{MW}_{\mathrm{E}}\right)$ and number of double bond present in fatty acid chain $\left(\mathrm{N}_{\mathrm{E}}\right)$ of individual ester molecule were considered as input variables, while their corresponding value in the data series were taken as output variable. Following this, mathematical correlation for each thermo-physical property was developed by fitting the variations in the values of that property for different molecular weight and degree of unsaturation linearly by means of statistical regression $[19,24]$. Thus, four different mathematical correlations (Eq. 1-4) dedicated for Density, Kinematic Viscosity, Cetane Number and Higher Heating Value) were developed for prediction purposes. Here, $\mathrm{N}_{\mathrm{E}}$ was taken as zero for saturated FAEs; and as one, two, so on for unsaturated FAEs depending on their degree of unsaturation.

$$
\begin{aligned}
& \text { Density }=881.86-\left(0.065 * M W_{E}\right)+\left(11.91 * N_{E}\right) \\
& \text { KinematicVis cosity }=-5.59+\left(0.03644 * M W_{E}\right)- \\
& -\left(0.784 * N_{E}\right)
\end{aligned}
$$

Cetane Number $=-4.92+\left(0.30 * M W_{E}\right)-\left(22.8 * N_{E}\right)(3)$

Higher Heating Value $=25.7+$

$$
+\left(0.057 * M W_{E} 0\right)-\left(3.16 * N_{E}\right)
$$

Numerous studies have proposed that thermo-physical properties of any biodiesel can be evaluated theoretically by considering mole or mass fraction along with properties of individual FAEs. Here, equation 5 represents the generalized expression for determining the properties based on mass fraction whereas equation 6 represents the generalized expression for determining the properties based on mole fraction.

$$
Y=\sum_{i=1}^{n} m i \cdot f i
$$

$$
Y=\sum_{i=1}^{n} x i \cdot f i
$$

where, $\mathrm{Y}$ is the thermo-physical property of the sample, $f_{i}$ is the thermo-physical property of the individual FAE, $m_{i}$ is mass fraction for the corresponding FAE, $x_{i}$ is the mole fraction of corresponding FAE determined using equation 7 by substituting the molecular weight of individual FAE along with its corresponding mass fraction.

$$
x_{i}=\frac{\frac{m_{i}}{M W t_{i}}}{\sum_{i=1}^{n}\left(\frac{m_{i}}{M W t_{i}}\right)}
$$

Similarly, the average absolute percentage error (AAPE) between the calculated and experimental values was determined using equation 8 :

$$
A A P E=\left(\frac{1}{n}\right) \sum_{i=1}^{n}\left|\left(\frac{\left(f_{i} \exp -f_{i} c a l\right)}{f_{i} c a l} * 100\right)\right|
$$

where, $\mathrm{n}$ is the number of fatty acid esters considered for the study, $f_{i} \exp$ and $f_{i}$ cal are the experimental and calculated thermo-physical properties.

\section{RESULTS AND DISCUSSIONS}

\subsection{Characterization and quantification of beef tallow biodiesel}

Waste beef tallow biodiesel was characterized using GC spectra (figure 1), which identified the FAEs molecules along with their $\%$ availability based on retention time of the peak and area occupied by the peak respectively. In total, 10 fatty acid ethyl esters were characterized from the waste tallow biodiesel; where ethyl myristate, ethyl palmitate, ethyl oleate and ethyl stearate were identified as dominant FAEs in view of their higher availability and were expected to have an influencing role in deciding the properties of biodiesel. Table 2 summarises the preliminary data like Molecular weight, Mass and Mole fraction, Degree of unsaturation of Characterized FAEs. Based on these characterized FAEs data, molecular formula of the waste tallow biodiesel was derived as $\mathrm{C}_{18} \mathrm{H}_{35} \mathrm{O}_{2}$ with an average molecular weight of $283.47 \mathrm{~g} / \mathrm{mol}$.

\subsection{Properties of fatty acid esters (FAEs):}

Apart from preliminary data, thermo-physical properties (density, kinematic viscosity, $\mathrm{CN}$ and $\mathrm{HHV}$ ) of characterized FAEs along with the theoretical values determined using the mathematical correlations (Equation 1 to 4) are presented in table 3. The experimental and theoretical values were compared for Average Absolute Deviation (AAD) and Average Absolute Percentage Error (AAPE); and were found to be: 0.28 and $0.064 \%$ for density; 0.044 and $2.815 \%$ for kinematic viscosity; 1.509 and $4.77 \%$ for $\mathrm{CN} ; 0.275$ and $1.368 \%$ for $\mathrm{HHV}$, respectively. Table 4 summarizes the absolute deviation and absolute percentage error between the reported and calculated values for individual fatty acid esters. 
From table 3, properties like kinematic viscosity, CN and HHV increased with molecular weight but decreased as number of double bonds increased; meanwhile, density decreased with increasing molecular weight and reduced degree of unsaturation. Indeed, the thermo-physical properties of FAEs are entirely dependent on their molecular weight and number of double bonds signifying their degree of unsaturation [3].

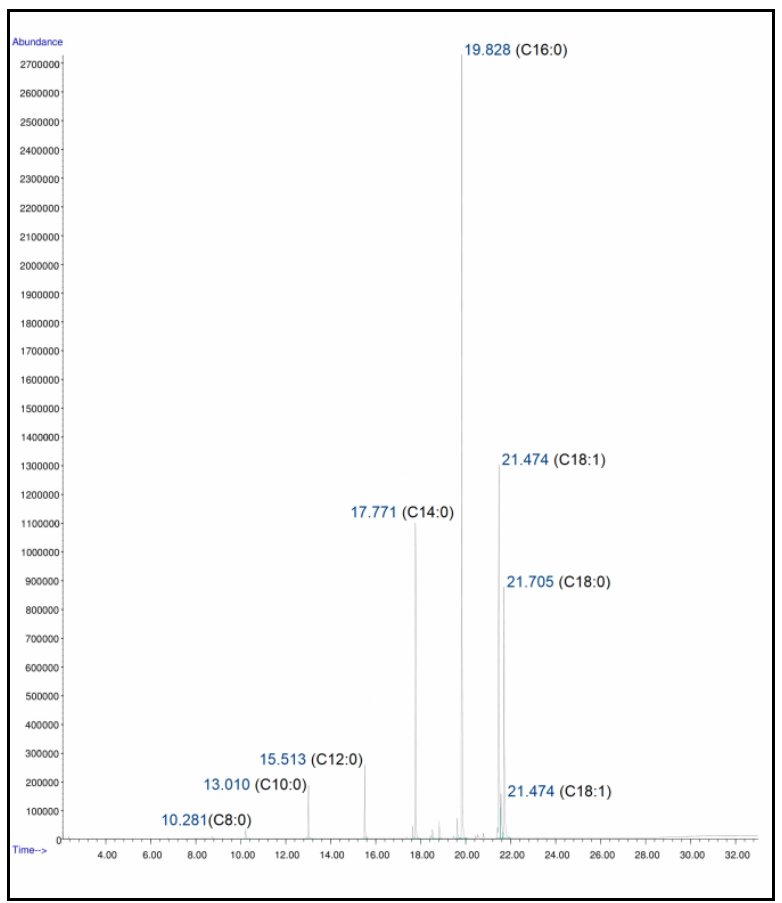

Figure1: GC Spectra of Waste Tallow Biodiesel

\section{Density:}

From equation 1 , it was clearly evident that density decreased with increase in molecular weight whereas increased with increase in degree of unsaturation. The inverse proportionality between density and molecular weight is signified by the negativity of latter function and the degree of unsaturation with positive sign signified the direct proportionality. In general, density of fatty acids is inversely proportional to their corresponding number of carbon atoms; and decreases marginally for higher number of carbon atoms [24, 25]. Accordingly, the density of FAEs also decreased significantly for esters with lower number of carbon atoms (C8 to C12) followed by marginal decrease in density for FAEs with higher number of carbon atoms. From figure 2, the experimental values were found to be well fit with the predicted model within the $95 \%$ confidence band and can be concluded that density decreased by $1.332 \mathrm{~kg} / \mathrm{m}^{3}$ on average for saturated FAEs whereas decreased by $1.45 \mathrm{~kg} / \mathrm{m}^{3}$ on average for unsaturated FAEs. Similarly, the density of unsaturated C14:1, C16:1 and C18:1 ethyl esters were found to be $1.41 \%$, $1.5 \%$ and $1.6 \%$ higher than the saturated C14:0, C16:0 and C18:0 ethyl esters, respectively. Eventually, the AAD and AAPE between the reported and predicted values were found to be 0.28 and $0.064 \%$, respectively.

\section{Kinematic Viscosity:}

From equation 2, it was clearly evident that kinematic viscosity increased with increase in molecular weight whereas decreased with increase in degree of unsaturation. Kinematic viscosity of FAEs was found to be directly proportional to its molecular weight and inversely proportional to its degree of unsaturation; and was demonstrated by their positive and negative sign respectively, in the equation. Based on the reported Kinematic Viscosity of fatty acid esters, it is evident that viscosity increases progressively along carbon chain length owing to the increasing Van der Waals forces along the nonpolar length of the ester molecule. Eventually, this Van der Waals intermolecular attraction is a resultant of zigzag arrangement of carbon atoms with tetrahedral bond angles along the linear fatty acid chain and occurs between SP3 hybridization atoms [24]. From figure 3, the experimental values were found to be well fit with the predicted model within the $95 \%$ confidence band and can be concluded that Kinematic viscosity increased by $0.685 \mathrm{~mm}^{2} / \mathrm{s}$ (on average) for saturated FAEs whereas Kinematic viscosity increased by $1.02 \mathrm{~mm}^{2} / \mathrm{s}$ ( on average) for unsaturated FAEs. In contrast, the viscosity of unsaturated $\mathrm{C} 14: 1, \mathrm{C} 16: 1$ and $\mathrm{C} 18: 1$ ethyl esters were found to be $18.27 \%, 16.3 \%$ and $18.16 \%$ lesser than the saturated $\mathrm{C} 14: 0, \mathrm{C} 16: 0$ and $\mathrm{C} 18: 0$ ethyl ester, respectively. In fact, reduction in viscosity for these unsaturated ester molecules was as a result of weak Van der Waals intermolecular attraction caused by their CIS-Configuration, which holds back the approaching SP2 atoms (from double bond) from neighbouring molecules. Ultimately, the AAD and AAPE between the reported and predicted values were found to be 0.044 and $2.815 \%$, respectively.

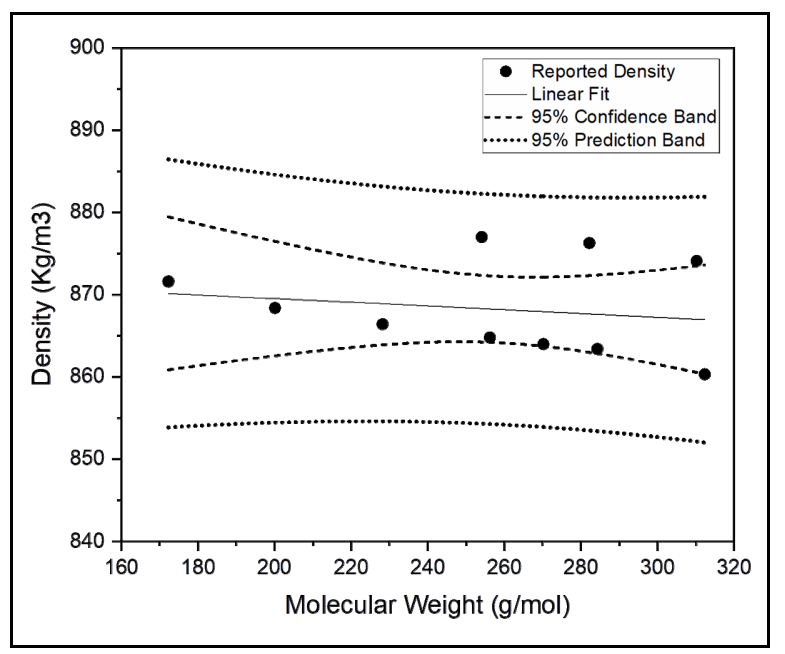

Figure 2 : Density of fatty acid esters as function of molecular weight

\section{Cetane Number (CN):}

From equation 3 , it was clearly evident that $\mathrm{CN}$ increased with increase in molecular weight whereas decreased with increase in degree of unsaturation. Like kinematic viscosity, cetane number of FAE was also found to be directly proportional to its molecular weight and inversely proportional to its degree of unsaturation. Accordingly, the positive and negative sign in the equation signified its direct and inverse proportionality with the molecular weight and degree of unsaturation of FAEs. In general, CN serves as an indicator for combustion speed and ignition delay; and increases for FAEs as their molecular weight increases. From figure 
4 , the experimental values were found to be well fit with the predicted model within the $95 \%$ confidence band and can be noted that $\mathrm{CN}$ increased by 6.38 units (on average) for saturated FAEs whereas $\mathrm{CN}$ increased by 6.96 units (on average) for unsaturated FAEs.However, the $\mathrm{CN}$ of unsaturated $\mathrm{C} 14: 1, \mathrm{C} 16: 1$ and $\mathrm{C} 18: 1$ ethyl esters were found to be $27.07 \%, 33.68 \%$ and $25.64 \%$ lesser than the saturated C14:0, C16:0 and C18:0 ethyl esters, respectively. Moreover, the reduction in $\mathrm{CN}$ for unsaturated esters was accounted by their unsaturated double bonds moving towards the center of the FAE chain. Further, the AAD and AAPE between the reported and predicted values were found to be 1.509 and $4.77 \%$, respectively.

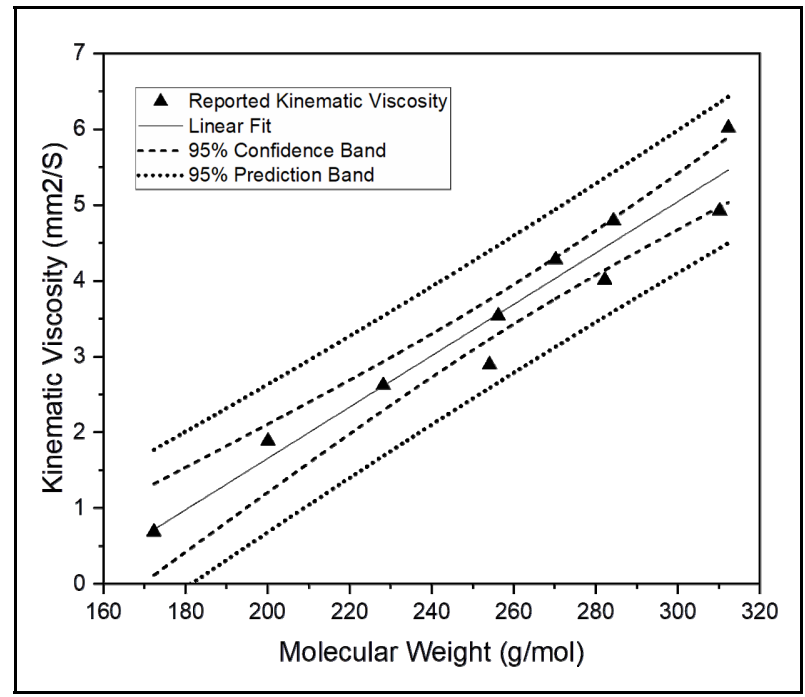

Figure 3 : Kinematic Viscosity of fatty acid esters as function of molecular weight

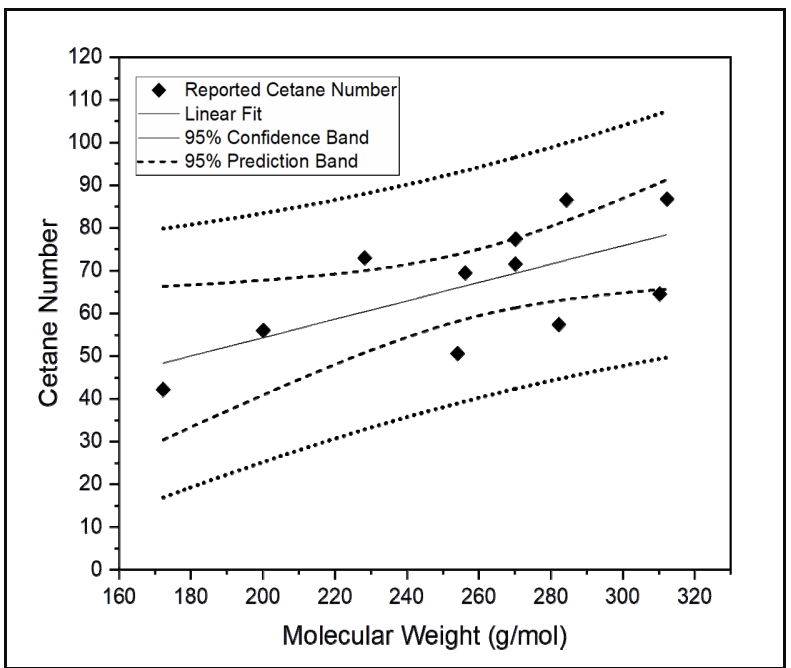

Figure 4: Cetane Number of fatty acid esters as function of molecular weight

From equation 4, it was clearly evident that HHV increased with increase in molecular weight whereas decreased with increase in degree of unsaturation. The HHV of FAEs was found to be directly proportional to its molecular weight and inversely proportional to its degree of unsaturation. Supporting this, the direct proportionality was signified by the positivity of molecular weight while inverse proportionality was accounted by its degree of unsaturation. Based on the reported HHV of FAEs, it is evident that the heating value increases progressively along carbon chain length owing to the increasing numberof $\mathrm{C}-\mathrm{H}$ bonds, which has higher bond enthalpy. From figure 5, the experimental values were found to be well fit with the predicted model within the $95 \%$ confidence band and can be concluded that $\mathrm{HHV}$ increased by $0.83 \mathrm{MJ} / \mathrm{kg}$ on average for saturated FAEs whereas HHV increased by $1.9 \mathrm{MJ} / \mathrm{kg}$ on average for unsaturated FAEs. In contrast, the HHV of unsaturated $\mathrm{C} 14: 1, \mathrm{C} 16: 1$ and $\mathrm{C} 18: 1$ ethyl esters were found to be $7 \%, 3.28 \%$ and $5.21 \%$ lesser than the saturated C14:0, C16:0 and C18:0 ethyl esters, respectively. This reduction in HHV for these unsaturated ester molecules is because of the lesser availability of hydrogen atoms (for $\mathrm{C}-\mathrm{H}$ bond) which lowers the heating value Inspite of availability of $\mathrm{C}=\mathrm{C}$ bond present in fatty acid carbon chain. Taken together, the AAD and AAPE between the reported and predicted values were found to be 0.275 and $1.368 \%$, respectively.

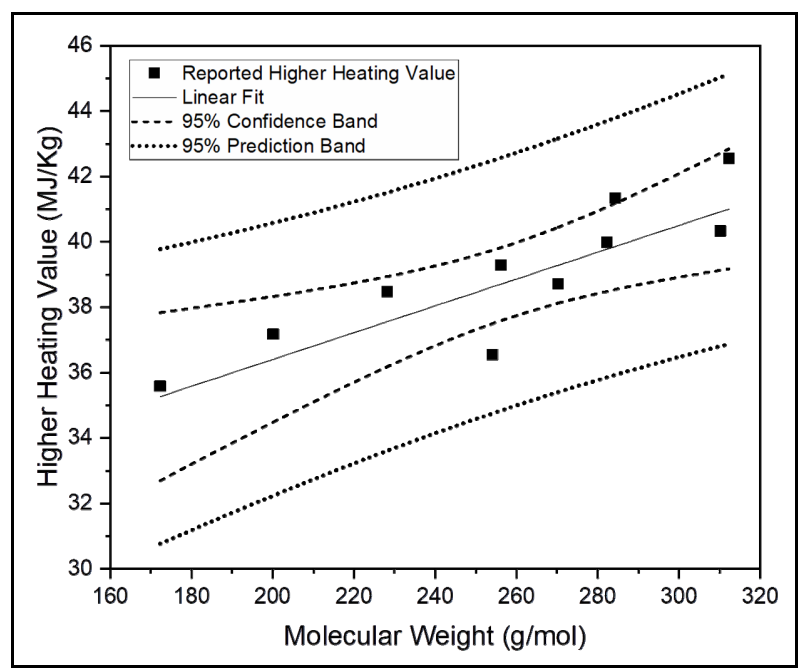

Figure 5 : Higher Heating Value of fatty acid esters as function of molecular weight

\subsection{Properties of Biodiesel}

\section{Density:}

Density describes the amount of fuel that can be occupied with its unit volume and is altered as temperature and pressure varies proportionally. In addition, density governs the fuel injection in CI engine where large amount of fuel will be injected for same volume in case of denser fuel when compared to less denser fuel. The density of biodiesel produced from waste beef tallow was determined by measuring the mass against a known volume and was measured as $883 \mathrm{~kg} / \mathrm{m}^{3}$. For waste beef tallow biodiesel, the $\mathrm{AD}$ in density between its experimental value and mole fraction/ mass fraction value was found to be 8.31 and 8.28 , respectively whereas their APE was found to be $1.92 \%$ and $1.91 \%$, respectively. However, upon comparing with other literatures $[23,26,27]$, AAD in the experimental value of density from their mole fraction and mass fraction value was found to be 3.55 and 3.57, respectively whereas the AAPE for density was found to be $0.82 \%$ (mole fraction) and $0.82 \%$ (mass fraction). Table 5 summarizes the AAD and AAPE for density between experimental value, mole fraction and mass faction method values. 
Table 2: Molecular weight, Mass and Mole fraction, Degree of unsaturation of Characterized FAEs

\begin{tabular}{|c|c|c|c|c|c|c|c|c|}
\hline $\begin{array}{l}\text { S. } \\
\text { No }\end{array}$ & $\begin{array}{l}\text { Carbon } \\
\text { Number }\end{array}$ & Fatty Acid Ester Name & $\begin{array}{l}\text { Molecular } \\
\text { Formula }\end{array}$ & $\begin{array}{c}\text { Molecular } \\
\text { Weight, } \\
\text { g/mol }\end{array}$ & $\begin{array}{c}\text { Number } \\
\text { of double } \\
\text { bonds }\end{array}$ & $\begin{array}{l}\text { Retention } \\
\text { Time }\end{array}$ & $\begin{array}{c}\text { Mass Fraction } \\
\text { (Availability,\%), } \\
\mathrm{m}_{\mathrm{i}} \text { value } \\
\end{array}$ & $\begin{array}{c}\text { Mole } \\
\text { Fraction, } \\
\mathrm{x}_{\mathrm{i}} \text { value }\end{array}$ \\
\hline 1 & C8:0 & Octanoic Acid Ethyl Ester & $\mathrm{C}_{10} \mathrm{H}_{20} \mathrm{O}_{2}$ & 172.28 & 0 & 10.220 & 0.46 & 0.0076 \\
\hline 2 & C10:0 & Decanoic Acid Ethyl Ester & $\mathrm{C}_{12} \mathrm{H}_{24} \mathrm{O}_{2}$ & 200.1 & 0 & 13.011 & 2.3 & 0.0326 \\
\hline 3 & C12:0 & Dodecanoic Acid Ethyl Ester & $\mathrm{C}_{14} \mathrm{H}_{28} \mathrm{O}_{2}$ & 228.2 & 0 & 15.511 & 3.13 & 0.0389 \\
\hline 4 & C14:1 & Ethyl 9-Tetradecenoate & $\mathrm{C}_{16} \mathrm{H}_{30} \mathrm{O}_{2}$ & 254.1 & 1 & 17.644 & 0.54 & 0.0060 \\
\hline 5 & C14:0 & Tetradecanoic Acid Ethyl Ester & $\mathrm{C}_{16} \mathrm{H}_{32} \mathrm{O}_{2}$ & 256.2 & 0 & 17.773 & 13.79 & 0.1526 \\
\hline 6 & C15:0 & Pentadecanoic Acid Ethyl Ester & $\mathrm{C}_{17} \mathrm{H}_{34} \mathrm{O}_{2}$ & 270.2 & 0 & 18.820 & 1.91 & 0.0090 \\
\hline 7 & C16:1 & E-11-Hexadecenoic Acid Ethyl Ester & $\mathrm{C}_{18} \mathrm{H}_{34} \mathrm{O}_{2}$ & 282.2 & 1 & 19.625 & 1.16 & 0.0117 \\
\hline 8 & $\mathrm{C} 16: 0$ & Hexadecanoic Acid Ethyl Ester & $\mathrm{C}_{18} \mathrm{H}_{36} \mathrm{O}_{2}$ & 284.3 & 0 & 19.830 & 37.36 & 0.3726 \\
\hline 9 & C18:1 & Oleic Acid Ethyl Ester & $\mathrm{C}_{20} \mathrm{H}_{38} \mathrm{O}_{2}$ & 310.2 & 1 & $\begin{array}{l}21.473 / \\
21.563\end{array}$ & 25.17 & 0.2301 \\
\hline 10 & C18:0 & Octadecanoic Acid Ethyl Ester & $\mathrm{C}_{20} \mathrm{H}_{40} \mathrm{O}_{2}$ & 312.3 & 0 & 21.706 & 14.78 & 0.1342 \\
\hline
\end{tabular}

Table 3: Experimental and predicted thermo-physical properties of characterized FAEs

\begin{tabular}{|c|c|c|c|c|c|c|c|c|}
\hline $\begin{array}{l}\text { Carbon } \\
\text { Number }\end{array}$ & $\begin{array}{c}\text { Density } \\
\left(\mathrm{kg} / \mathrm{m}^{3}\right) \\
(\text { Reported } \\
\left.@ 15^{\circ} \mathrm{C}\right)\end{array}$ & $\begin{array}{c}\text { Density } \\
\left(\mathrm{kg} / \mathrm{m}^{3}\right) \\
(\text { Calculated } \\
\left.\text { @ } 15^{\circ} \mathrm{C}\right)\end{array}$ & $\begin{array}{l}\text { Kinematic } \\
\text { Viscosity } \\
\left(\mathrm{mm}^{2} / \mathrm{s}\right) \\
(\text { Reported } \\
\left.\text { @ } 40^{\circ} \mathrm{C}\right)\end{array}$ & $\begin{array}{l}\text { Kinematic } \\
\text { Viscosity } \\
\left(\mathrm{mm}^{2} / \mathrm{s}\right) \\
(\text { Calculated } \\
\left.(a) 40^{\circ} \mathrm{C}\right)\end{array}$ & $\begin{array}{c}\text { Cetane } \\
\text { Number } \\
\text { (Reported) }\end{array}$ & $\begin{array}{c}\text { Cetane } \\
\text { Number } \\
\text { (Calculated) }\end{array}$ & $\begin{array}{c}\text { Higher } \\
\text { Heating } \\
\text { Value } \\
\text { (MJ/kg) } \\
\text { (reported) }\end{array}$ & $\begin{array}{c}\text { Higher } \\
\text { Heating } \\
\text { Value } \\
\text { (MJ/kg) } \\
\text { (Calculated) }\end{array}$ \\
\hline & {$[3,23]$} & & {$[3,23]$} & & {$[3,23]$} & & {$[3,23]$} & \\
\hline C8:0 & 871.60 & 870.66 & 0.69 & 0.69 & 42.20 & 46.76 & 35.58 & 35.52 \\
\hline C10:0 & 868.40 & 868.85 & 1.89 & 1.70 & 56.00 & 55.11 & 37.18 & 37.11 \\
\hline C12:0 & 866.40 & 867.03 & 2.62 & 2.73 & 73.00 & 63.54 & 38.47 & 38.71 \\
\hline C14:1 & 877.00 & 877.25 & 2.89 & 2.89 & 50.65 & 48.51 & 36.55 & 37.02 \\
\hline C14:0 & 864.80 & 865.21 & 3.54 & 3.75 & 69.45 & 71.94 & 39.29 & 40.30 \\
\hline C15:0 & 864.00 & 864.30 & 4.28 & 4.26 & 77.42 & 76.14 & 40.46 & 41.10 \\
\hline C16:1 & 876.30 & 875.43 & 4.01 & 3.91 & 57.40 & 56.94 & 39.99 & 38.63 \\
\hline C16:0 & 863.40 & 863.38 & 4.79 & 4.77 & 86.55 & 80.37 & 41.34 & 41.91 \\
\hline C18:1 & 874.10 & 873.61 & 4.92 & 4.93 & 64.57 & 65.34 & 40.34 & 40.22 \\
\hline C18:0 & 860.33 & 861.56 & 6.02 & 5.79 & 86.83 & 88.77 & 42.55 & 43.50 \\
\hline
\end{tabular}

Table 4: Absolute Deviation (AD) and Absolute Percentage Error (APE) between experimental and predicted values for characterized FAEs

\begin{tabular}{|c|c|c|c|c|c|c|c|c|}
\hline \multirow{2}{*}{$\begin{array}{c}\text { Carbon } \\
\text { Number }\end{array}$} & \multicolumn{2}{|c|}{ Density } & \multicolumn{2}{c|}{ Kinematic Viscosity } & \multicolumn{2}{c|}{ Cetane Number } & \multicolumn{2}{c|}{ Higher Heating Value } \\
\cline { 2 - 10 } & AD & APE, $\%$ & AD & APE, $\%$ & AD & APE, $\%$ & AD & APE, $\%$ \\
\hline C $8: 0$ & 0.469 & 0.108 & 0.000 & 0.001 & 2.282 & 9.760 & 0.031 & 0.175 \\
\hline C10:0 & 0.227 & 0.052 & 0.093 & 10.881 & 0.445 & 1.615 & 0.036 & 0.195 \\
\hline C14:1 & 0.314 & 0.072 & 0.052 & 3.823 & 4.730 & 14.888 & 0.120 & 0.621 \\
\hline C14:0 & 0.127 & 0.029 & 0.003 & 0.229 & 1.069 & 4.405 & 0.239 & 1.290 \\
\hline C15:0 & 0.204 & 0.047 & 0.104 & 5.540 & 1.245 & 3.461 & 0.505 & 2.507 \\
\hline C16:1 & 0.436 & 0.140 & 0.051 & 2.625 & 0.230 & 0.808 & 0.680 & 3.523 \\
\hline C16:0 & 0.010 & 0.002 & 0.012 & 0.487 & 3.090 & 7.689 & 0.282 & 1.344 \\
\hline C18:1 & 0.247 & 0.056 & 0.003 & 0.121 & 0.385 & 1.178 & 0.057 & 0.285 \\
\hline C18:0 & 0.615 & 0.143 & 0.113 & 3.899 & 0.970 & 2.185 & 0.474 & 2.179 \\
\hline Average & $\mathbf{0 . 2 8}$ & $\mathbf{0 . 0 6 4}$ & $\mathbf{0 . 0 4 4}$ & $\mathbf{2 . 8 1 5}$ & $\mathbf{1 . 5 0 9}$ & $\mathbf{4 . 7 7}$ & $\mathbf{0 . 2 7 5}$ & $\mathbf{1 . 3 6 8}$ \\
\hline
\end{tabular}

Table 5: Density of waste tallow and other feedstock biodiesel samples. AAD and AAPE between experimental and calculated values

\begin{tabular}{|c|c|c|c|}
\hline \multirow{2}{*}{ Source } & \multicolumn{3}{|c|}{ Density, $\mathrm{kg} / \mathrm{m}^{3}$} \\
\cline { 2 - 4 } & Reported Value & $\begin{array}{c}\text { Mole Fraction Method } \\
\rho_{\text {biodiesel }}=\sum_{i=1}^{n} x_{i} \cdot \rho_{i}\end{array}$ & $\begin{array}{c}\text { Mass Fraction Method } \\
\rho_{\text {biodiesel }}=\sum_{i=1}^{n} m_{i} \cdot \rho_{i}\end{array}$ \\
\cline { 2 - 4 } & & (Calculated) & (Calculated) \\
\hline Beef Tallow Ethyl ester & 883 & 866.4 & 866.4 \\
\hline Rapeseed oil Ethyl ester [23] & 878.6 & 876.7 & 876.5 \\
\hline Waste animal fat ethyl ester [26] & 870 & 873.5 & 876.9 \\
\hline Waste frying oil ethyl ester [27] & 883 & 876.7 & $\mathbf{3 . 5 7}$ \\
\hline Average Absolute Deviation & - & $\mathbf{3 . 5 5}$ & $\mathbf{0 . 8 2}$ \\
\hline Average Absolute Percentage Error, $\%$ & - & $\mathbf{0 . 8 2}$ & \\
\hline
\end{tabular}


Table 6: Kinematic Viscosity of waste tallow and other feedstock biodiesel samples. AAD and AAPE between experimental and calculated values

\begin{tabular}{|c|c|c|c|}
\hline \multirow{2}{*}{ Source } & \multicolumn{3}{|c|}{ Kinematic Viscosity, $\mathrm{mm}^{2} / \mathrm{s}$} \\
\cline { 2 - 4 } & Reported Value & $\begin{array}{c}\text { Mole Fraction Method } \\
v_{\text {biodiesel }}=\sum_{i=1}^{n} x_{i} \cdot v_{i}\end{array}$ & $\begin{array}{c}\text { Mass Fraction Method } \\
v_{\text {biodiesel }}=\sum_{i=1}^{n} m_{i} \cdot v_{i}\end{array}$ \\
\hline & (Experimental) & (Calculated) & (Calculated) \\
\hline Beef Tallow Ethyl ester & 4.6 & 4.55 & 5.64 \\
\hline Rapeseed oil Ethyl ester [23] & 5.51 & 4.99 & 4.06 \\
\hline Waste animal fat ethyl ester [26] & 4.72 & 4.72 & 4.53 \\
\hline Waste frying oil ethyl ester [27] & 4.9 & 4.52 & $\mathbf{0 . 1 1}$ \\
\hline Average Absolute Deviation & - & $\mathbf{0 . 1 2}$ & $\mathbf{4 . 5 3}$ \\
\hline
\end{tabular}

Table 7: Cetane Number of waste tallow and other feedstock biodiesel samples. AAD and AAPE between experimental and calculated values

\begin{tabular}{|c|c|c|c|}
\hline \multirow{2}{*}{ Source } & \multicolumn{3}{|c|}{ Cetane Number } \\
\cline { 2 - 4 } & Reported Value & $\begin{array}{c}\text { Mole Fraction Method } \\
C N_{\text {biodiesel }}=\sum_{i=1}^{n} x_{i} \cdot C N_{i}\end{array}$ & $\begin{array}{c}\text { Mass Fraction Method } \\
C N_{\text {biodiesel }}=\sum_{i=1}^{n} m_{i} \cdot C N_{i}\end{array}$ \\
\cline { 2 - 4 } & (Experimental) & (Calculated) & (Calculated) \\
\hline Beef Tallow Ethyl ester & 69 & 74.5 & 64.9 \\
\hline Rapeseed oil Ethyl ester [23] & 63.6 & 60.9 & 58.6 \\
\hline Waste frying oil ethyl ester [27] & 53.5 & 58.4 & 63.3 \\
\hline waste fryer grease ethyl ester [28] & 60.4 & 66.3 & $\mathbf{1 . 9 2}$ \\
\hline Average Absolute Deviation & - & $\mathbf{2 . 3 6}$ & $\mathbf{5 . 8 8}$ \\
\hline Average Absolute Percentage Error,\% & - & $\mathbf{7 . 2 4}$ & \\
\hline
\end{tabular}

Table 8: Higher Heating Value of waste tallow and other feedstock biodiesel samples. AAD and AAPE between experimental and calculated values

\begin{tabular}{|c|c|c|c|}
\hline \multirow{2}{*}{ Source } & \multicolumn{3}{|c|}{ Higher Heating Value, MJ/kg } \\
\cline { 2 - 4 } & Reported Value & $\begin{array}{c}\text { Mole Fraction Method } \\
H H V_{\text {biodiesel }}=\sum_{i=1}^{n} x_{i} \cdot H H V_{i}\end{array}$ & $\begin{array}{c}\text { Mass Fraction Method } \\
H H V_{\text {biodiesel }}=\sum_{i=1}^{n} m_{i} \cdot H H V_{i}\end{array}$ \\
\cline { 2 - 4 } & (Experimental) & (Calculated) & 41.182 \\
\hline Beef Tallow Ethyl ester & 41 & 41.08 & 39.866 \\
\hline Rapeseed oil Ethyl ester [23] & 39.482 & 39.74 & 39.413 \\
\hline Waste frying oil ethyl ester [27] & 40.051 & 39.439 & 40.013 \\
\hline waste fryer grease ethyl ester [28] & 40.72 & 41.507 & $\mathbf{0 . 2 4}$ \\
\hline Average Absolute Deviation & - & $\mathbf{0 . 2 2}$ & $\mathbf{1 . 2 0}$ \\
\hline Average Absolute Percentage Error, $\%$ & - & $\mathbf{1 . 0 8}$ & \\
\hline
\end{tabular}

\section{Kinematic Viscosity:}

Kinematic viscosity describes the internal resistance to fluid's flow when gravity acts on it; and increases for biodiesel with high carbon chained FAEs. Spray characteristics of fuel like droplet size and penetration, effectiveness of atomization are deeply influenced by the kinematic viscosity and tends to produce larger droplets accompanied with poor atomization for high viscosity biodiesel, resulting in reduced combustion and increased cylinder deposits. Apart from spray characteristics, higher viscosity fuel requires more pump work which causes increased wear rate for fuel injection components thereby reducing the engine performance rate. The kinematic viscosity of biodiesel produced from waste beef tallow was determined according to ASTM D 445 specification and was calculated as $4.6 \mathrm{~mm}^{2} / \mathrm{s}$, which was found to be well inside the permissible range $\left(1.9-6 \mathrm{~mm}^{2} / \mathrm{s}\right)$. For waste beef tallow biodiesel, the $\mathrm{AD}$ in kinematic viscosity between its experimental value and mole fraction/mass fraction value was found to be 0.03 and 0.02 respectively whereas their APE was found to be $1.1 \%$ and $0.86 \%$, respectively. However, upon comparing with other literatures $[23,26,27]$, AAD in the experimental value of kinematic viscosity from their mole fraction and mass fraction value was found to be 0.12 and 0.11 , respectively whereas the AAPE for kinematic viscosity was found to be $4.98 \%$ (mole fraction) and $4.48 \%$ (mass fraction). Table 6 summarizes the AAD and AAPE for kinematic viscosity between experimental value, mole fraction and mass faction method values.

\section{Cetane Number (CN):}

Cetane Number serves as an indicator for combustion speed and ignition delay; and increases for biodiesel with high saturated FAEs. Biodiesel with higher $\mathrm{CN}$ provide complete combustion accompanied by smooth running of engine whereas lower $\mathrm{CN}$ results in increased exhaust emission owing to incomplete combustion. In addition, higher $\mathrm{CN}$ improves the coldstart behaviour and reduces knocking and white smoke. The CN of biodiesel produced from waste beef tallow biodiesel was determined according to ASTM D613 standard and was measured as 69 , which was $46.81 \%$ greater than the minimum required limit. For waste beef tallow biodiesel, the $\mathrm{AD}$ in $\mathrm{CN}$ between its experimental value and mole fraction/ mass fraction 
value was found to be 2.75 and 2.9 , respectively whereas their APE was found to be $7.38 \%$ and $7.88 \%$, respectively. However, upon comparing with other literatures [23,27,28], AAD in the experimental value of $\mathrm{CN}$ from their mole fraction and mass fraction value was found to be 2.36 and 1.9 , respectively whereas the AAPE for $\mathrm{CN}$ was found to be $7.24 \%$ (mole fraction) and $5.87 \%$ (mass fraction). Table 7 summarizes the $\mathrm{AAD}$ and AAPE for $\mathrm{CN}$ between experimental value, mole fraction and mass faction method values.

\section{Higher Heating Value (HHV):}

Higher Heating Value of biodiesel signifies the energy content available in that biofuel and was found according to ASTM D240 specifications. Accordingly, the HHV of biodiesel produced from waste beef tallow was found to be $41 \mathrm{MJ} / \mathrm{kg}$ and was $21.09 \%$ lesser than the HHV of diesel fuel (49.65 MJ/kg) [29]; and was accounted by the presence of oxygen and absence of sulphur molecules in their esters molecule which reduced it considerably [23]. For waste beef tallow biodiesel, the AD in HHV between its experimental value and mole fraction/ mass fraction value was found to be 0.04 and 0.09 , respectively whereas their APE was found to be $0.20 \%$ and $0.44 \%$, respectively. However, upon comparing with other literatures $[23,27,28]$, AAD in the experimental value of $\mathrm{HHV}$ from their mole fraction and mass fraction value was found to be 0.22 and 0.24 , respectively whereas the AAPE for HHV was found to be $1.08 \%$ (mole fraction) and $1.20 \%$ (mass fraction). Table 8 summarizes the AAD and AAPE for HHV between experimental value, mole fraction and mass faction method values.

Based on the study, it was evident that the thermophysical properties like density, Kinematic Viscosity, $\mathrm{CN}$, HHV were entirely dependent on the properties of individual FAEs. Moreover, equation 5 (mass fraction method) clearly indicates that the major contribution in each thermo-physical property of the biodiesel were significantly contributed by ethyl myristate, ethyl palmitate, ethyl oleate and ethyl stearate available in higher concentrations than compared to other characterized FAEs.

However, these equations are limited with certain restrictions in predicting thermo-physical properties which are as follows:

(i) Equations for predicting density and Kinematic Viscosity are restricted for temperatures $15^{\circ} \mathrm{C}$ and $40^{\circ} \mathrm{C}$ respectively, owing to development of mathematical equation based on the data series obtained at these temperatures. Equations incorporating temperature as the third variable along with the existing variables can be developed to find these properties at different temperatures.

(ii) These developed equations work well for prediction of thermo-physical properties of ethanol based biodiesel (fatty acid ethyl esters) only; and cannot be used for predicting the thermo-physical properties of other fatty acid alkyl esters (methyl, propyl and so on except ethyl). However, introducing the number of carbon atoms in alcohol moiety as a variable can help us in developing predictive models for any type of FAEs.

\section{CONCLUSIONS}

Thus, theoretical prediction of thermo-physical properties like density, kinematic viscosity, cetane number and higher heating value of waste tallow biodiesel was carried out successfully. Some of the major conclusions drawn from this computational study are as follows:

(i) Thermo-physical properties of tallow and other feedstocks biodiesel were entirely dependent on their fatty acid esters profile, which in turn was influenced by the molecular weight and degree of unsaturation of these ester molecules.

(ii) Properties like kinematic viscosity, cetane number and higher heating value increased with increasing molecular weight and degree of saturation; whereas density increased for higher degree of unsaturation and reduced molecular weights.

(iii) Experimental and predicted values of the characterized FAEs in tallow biodiesel were found to be with minimal deviation and \% error; which signified the accuracy in developed correlations.

(iv) Likewise, the experimental and predicted values of tallow biodiesel and other biodiesel were in good agreement with each other; along with minimal deviation between the values calculated using mole fraction and mass fraction, thereby recommending both for prediction purposes.

In conclusion, it is clearly evident that properties of any biodiesel simply depends on its FAEs profile as a function of their structural properties (molecular weight, number of double bonds). Thus, any property related to biodiesel can be easily predicted by developing correlations using these structural properties; however, introducing additional variables like temperature (for density, viscosity) and number of carbon atoms in alcohol moiety can overcome the restrictions related to the usage of these correlations for a single group of alkyl esters alone. This investigation also briefs out the significance of FAEs in deciding the biodiesel properties, which again defines the precursors needed for choosing ideal fatty acids (direct selection or blending multiple feedstocks) for developing highly efficient sustainable biodiesel.

\section{REFERENCES}

[1] Srinivasan, G.R., Jambulingam, R., 2018. Comprehensive Study on Biodiesel Produced from Waste Animal Fats-A Review. Journal of Environmental Science and Technology, 11, pp.157-166.

[2] Srinivasan, G.R., Shankar, V. and Jambulingam, R., 2019. Experimental study on influence of dominant fatty acid esters in engine characteristics of waste beef tallow biodiesel. Energy Exploration \& Exploitation, 37(3), pp.1098-1124.

[3] Knothe, G., 2005. Dependence of biodiesel fuel properties on the structure of fatty acid alkyl esters. Fuel processing technology, 86(10), pp.1059-1070.

[4] Pratas, M.J., Freitas, S.V., Oliveira, M.B., Monteiro, S.C., Lima, Á.S. and Coutinho, J.A., 2011. Biodiesel density: Experimental measurements and prediction models. Energy \& Fuels, 25(5), pp.2333-2340. 
[5] Boudy, F. and Seers, P., 2009. Impact of physical properties of biodiesel on the injection process in a common-rail direct injection system. Energy Conversion and Management, 50(12), pp.2905-2912.

[6] Blangino, E., Riveros, A.F. and Romano, S.D., 2008. Numerical expressions for viscosity, surface tension and density of biodiesel: analysis and experimental validation. Physics and Chemistry of liquids, 46(5), pp.527-547.

[7] Freitas, S.V., Pratas, M.J., Ceriani, R., Lima, A.S. and Coutinho, J.A., 2011. Evaluation of predictive models for the viscosity of biodiesel. Energy \& Fuels, 25(1), pp.352-358.

[8] Refaat, A.A., 2009. Correlation between the chemical structure of biodiesel and its physical properties. International Journal of Environmental Science \& Technology, 6(4), pp.677-694.

[9] Munir, M., Saeed, M., Ahmad, M., Waseem, A., Sultana, S., Zafar, M. and Srinivasan, G.R., 2019. Optimization of novel Lepidium perfoliatum Linn. Biodiesel using zirconium-modified montmorillonite clay catalyst. Energy Sources, Part A: Recovery, Utilization, and Environmental Effects, pp.1-16.

[10] Shu, Q., Yang, B., Yang, J. and Qing, S., 2007. Predicting the viscosity of biodiesel fuels based on the mixture topological index method. Fuel, 86(12-13), pp.1849-1854.

[11] Heywood, J.B. Internal Combustion Engine Fundamentals; McGraw-Hill: New York, NY, USA, 1988.

[12] Giakoumis, E.G. and Sarakatsanis, C.K., 2019. A comparative assessment of biodiesel cetane number predictive correlations based on fatty acid composition. Energies, 12(3), p.422.

[13] Jambulingam R, Shankar V, Palani S and Srinivasan GR (2019) Effect of Dominant Fatty Acid Esters on Emission Characteristics of Waste Animal Fat Biodiesel in CI Engine. Frontiers in Energy Research, 7, p.63.

[14] Knothe, G., 2014. A comprehensive evaluation of the cetane numbers of fatty acid methyl esters. Fuel, 119, pp.6-13.

[15] Fassinou, W.F., 2012. Higher heating value (HHV) of vegetable oils, fats and biodiesels evaluation based on their pure fatty acids' HHV. Energy, 45(1), pp. 798-805.

[16] Gopinath, A. et al., 2009. Theoretical modeling of iodine value and saponification value of biodiesel fuels from their fatty acid composition. Renewable Energy, 34(7), pp. 1806-1811.

[17] Pratas, M.J. et al., 2010. Densities and viscosities of fatty acid methyl and ethyl esters. Journal of Chemical \& Engineering Data, 55(9), pp.39833990.

[18] Jekayinfa, S.O., Adebayo, A.O., Sulaiman, M.A. and Ayoola, V.O., 2019. Prediction of Density and Viscosity of Biodiesel Fuel from Fatty Acid Methyl Ester (FAME) Composition. Arid Zone Journal of Engineering, Technology and Environment, 15(3), pp.519-533.
[19]Roosta, A. and Bardool, R., 2019. A Predictive Correlation for Dynamic Viscosity of Fatty Acid Methyl Esters and Biodiesel. Journal of the American Oil Chemists' Society, 96(7), pp.741750 .

[20]Hong, I.K., Lee, J.R. and Lee, S.B., 2015. Fuel properties of canola oil and lard biodiesel blends: Higher heating value, oxidative stability, and kinematic viscosity. Journal of Industrial and Engineering Chemistry, 22, pp.335-340.

[21] Ranjitha, J., Raghavendra, S.G., Vijayalakshmi, S. and Deepanraj, B., 2019. Production, optimisation and engine characteristics of beef tallow biodiesel rendered from leather fleshing and slaughterhouse wastes. Biomass Conversion and Biorefinery, pp.1-14.

[22] Srinivasan, G.R., Palani, S. and Jambulingam, R., 2018. Biodiesel production from waste animal fat using a novel catalyst HCA immobilized AuNPS amine grafted SBA-15. Journal of Engineering Science and Technology, 13(8), pp.2632-2643.

[23]Barabás, I. and Todoruț, I.A., 2011. Biodiesel quality, standards and properties. Biodieselquality, emissions and by-products, pp.3-28.

[24] Ramírez-Verduzco, L.F., Rodríguez-Rodríguez, J.E. and del Rayo Jaramillo-Jacob, A., 2012. Predicting cetane number, kinematic viscosity, density and higher heating value of biodiesel from its fatty acid methyl ester composition. Fuel, 91(1), pp.102-111.

[25] Gouw, T.H. and Vlugter, J.C., 1964. Physical properties of fatty acid methyl esters. I. Density and molar volume. Journal of the American Oil Chemists' Society, 41(2), pp.142-145.

[26] Cunha Jr, A., Feddern, V., Marina, C., Higarashi, M.M., de Abreu, P.G. and Coldebella, A., 2013. Synthesis and characterization of ethylic biodiesel from animal fat wastes. Fuel, 105, pp.228-234.

[27] Sanli, H., Alptekin, E. and Canakci, M., 2019. Production of Fuel Quality Ethyl Ester Biodiesel: 1. Laboratory-Scale Optimization of Waste Frying Oil Ethanolysis, 2. Pilot-Scale Production with the Optimal Reaction Conditions. Waste and Biomass Valorization, 10(7), pp.1889-1898.

[28] Issariyakul, T., Kulkarni, M.G., Dalai, A.K. and Bakhshi, N.N., 2007. Production of biodiesel from waste fryer grease using mixed methanol/ethanol system. Fuel Processing Technology, 88(5), pp.429-436.

[29] Sivaramakrishnan, K. and Ravikumar, P., 2011. Determination of higher heating value of biodiesels. International Journal of Engineering Science and Technology, 3(11), pp.7981-7987.

\section{ТЕОРИЈСКО ПРЕДВИЪАЊЕ ТЕРМО- ФИЗИЧКИХ СВОЈСТАВА БИОДИЗЕЛА БАЗИРАНОГ НА ГОВЕЪЕМ ЛОЈУ}

\section{Г.Р. Шринивасан, Р. Јамбулингам}

Рад се бави теоријским предвиђањем термо-физичких својстава биодизела добијеног од отпадног говеђег 
лоја развијањем математичких корелација помоћу естара масних киселина. Лој је набављен из кланице и штавионице и трансестерификацијом додавањем базног катализатора добијен је биодизел. Етил палмитат (С $16: 0)$, етил олеат (С $18: 1)$ и етил стеарат (С $18: 0)$ су одређени као доминантни естри масних киселина у биодизелу са дистрибуцијом од $37,36 \%, 25,17 \%$ и $14,78 \%$. Развијене су математичке корелације за предвиђање густине, кинематичког вискозитета, цетанског броја и веће топлотне вредности коришћењем статистичке регресије при чему су улазне променљиве биле молекулска тежина и број незасићених веза масних киселина. Термо-физичка својства су израчуната на основу срачунавања корелација, масене фракције и молске фракције карактеристичних естара масних киселина и добијени резултати су упоређени према ASTM D976 стандарду. Средње апсолутно одступање и средња апсолутна процентна грешка су имали следеће вредности: густина - 3,55 и $0,815 \%$, кинематички вискозитет 0,12 и 4,79\%, цетански број - 2,14 и 6,56\%, већа топлотна вредност - 0,23 и 1,14\%. Корелације су показале да кинематички вискозитет, цетански број и већа топлотна вредност расту са порастом молекулске тежине естара масних киселина, али да опадају са порастом незасићености молекула естра. Густина биодизела се повећава са незасићеношћу а опада са повећањем молекулске тежине. Предвиђене вредности наведених параметара се добро слажу са вредностима добијеним експериментом. 